\title{
The strategic importance of identifying knowledge-based and intangible assets for generating value, competitiveness and innovation in sub-Saharan Africa
}

\author{
Ezra Ondari-Okemwa' \\ Department of Library and Information Science, University of Fort Hare, South Africa \\ EOndari@ufh.ac.za
}

\begin{abstract}
Received 10 August 2010
Accepted I 2 July 201 I

This article discusses the strategic importance of identifying intangible assets for creating value and enhancing competitiveness and innovation in science and technology in a knowledge economy with particular reference to the subSaharan Africa region. It has always been difficult to gather the prerequisite information to manage such assets and create value from them. The paper discusses the nature of intangible assets, the characteristics of a knowledge economy and the role of knowledge workers in a knowledge economy. The paper also discusses the importance of identifying intangible assets in relation to capturing the value of such assets, the transfer of intangible assets to other owners and the challenges of managing organizational intangible assets. Objectives of the article include: underscoring the strategic importance of identifying intangible assets in sub-Saharan Africa; examining the performance of intangible assets in a knowledge economy; how intangible assets may generate competitiveness, economic growth and innovation; and assess how knowledge workers are becoming a dominant factor in the knowledge economy. An extensive literature review was employed to collect data for this article. It is concluded in the article that organizations and governments in sub-Saharan Africa should look at knowledge-based assets as strategic resources, even though the traditional accounting systems may still be having problems in determining the exact book value of such assets. It is recommended that organizations and government departments in sub-Saharan Africa should implement a system of the reporting of the value of intangible organizational assets just like the reporting of the value of tangible assets; and that organizations in sub-Saharan Africa should use knowledge to produce "smart products and services" which command premium prices.
\end{abstract}

Keywords: Intangible assets; Identification; Knowledge economy; Knowledge workers; Sub-Saharan Africa

\section{Introduction}

The expansion of the services sector, globalization, deregulation and the emergence of new information and communication technologies (ICTs) have brought to the fore the issue of how knowledge is created, disseminated, retained and used to obtain economic returns (Organization for Economic Corporation and Development (OECD), 2008). This development is associated with a structural change from traditional scale-based manufacturing to new more innovation-intensive activities. These rely heavily on intangible assets encompassing such elements as research and development, patents, software, human resources and new organisational structures. These assets have become strategic factors for value creation by firms. They are increasingly important in enabling productivity and efficiency gains, and are a crucial part of innovation in relation to business processes and products. As such, intangible assets are central to economies' growth and competitiveness.

Many organizations in the developed world are now realizing that their knowledge-based and intangible assets can generate wealth and profits. However, organizations in sub-Saharan Africa are yet to embrace the strategic importance of intangible assets for creating value and enhancing competitiveness and innovation. According to the World Bank (20I I), the promotion of innovation, in particular, technological innovation, in developing countries is becoming a fashionable subject. The growing interest in the subject stems from the recognition that it is necessary to go back to basics after experiencing the limits of traditional economic policies encapsulated in the "Washington consensus" approach. Innovation goes hand-in-hand with development. As a developing region, sub-Saharan Africa is one region which needs sustainable economic growth.

Knowledge-based and intangible assets may have been there since the beginning of human civilization, but it has always been difficult if not impossible to gather the prerequisite information to manage and value such assets. This may be attributed to the fact that there have always not been standards for measuring the value of intangible assets. Standards for valuing intangible assets have been developed and it is now relatively easier to measure and value such assets. The situation is worse in sub-Saharan Africa where a shortage of expertise for identifying and valuing knowledge-based and intangible assets, just like there is short supply of expertise in many technical areas. Intangible assets are those assets that

I. Ezra Ondari-Okemwa (PhD) is an associate professor in the Department of Library and Information Science at the University of Fort Hare in South Africa. 
are of value but cannot be physically touched such as brand, franchise, trademark, patents, copyrights, goodwill and various types of permits. Such assets are non-monetary and are created through time and/or effort and can be identified as separate assets. Knowledge embodied in intellectual assets (e.g. human capital, research and development (R\&D), patents, software and organisational structures) is becoming crucial for firms' and countries' economic performance and growth (OECD 2006). The OECD further argues that in this new environment, characterized by increasingly global markets, including those for intellectual assets, companies need to be able to earn economic returns from both developing and using intellectual assets. Policymakers need to ensure that the beneficial effects of intellectual assets are spread throughout the economy, thereby encouraging the dissemination of best practices, and that an appropriate balance is maintained between the legal control and diffusion of knowledge.

Such assets can be categorized into legal and competitive intangibles. Legal intangibles are known under the generic term of 'intellectual property' and are responsible for generating legal property rights capable of defense in a court of law. Competitive intangibles may not be owned but directly impact on effectiveness, productivity, wastage, and opportunity costs within an organization or an economy, hence impacting on costs, revenues, quality of customer service, satisfaction, market value and share price.

There is no doubt that the economic rules have drastically changed and will continue changing in the $21^{\text {st }}$ century. Economic rules now recognize intangible assets as factors of production, which means that public policy has also to change. However, public policy in sub-Saharan Africa has not changed to catch up with the changing economic rules. There is no evidence that governments in sub-Saharan Africa have come to terms with how to utilize information, foster development of intangibles, and promote innovation and competitiveness in this new economy. Policymakers in the region are yet to frame policy questions in light of the changing economic realities.

Issues of developing and utilizing information, managing intangibles, and fostering innovation underlie discussions on a variety of subjects, such as intellectual property rights, education and training policy, economic development, technology policy, and trade policy. Crafting new policies in these areas requires infusing a better understanding of intangibles and the information economy into the public debate in sub-Saharan Africa.

Andreou, Green and Stankosky (2007) argue that intangible assets have been identified as the most critical resource of today's business enterprise even though most business organizations are not in a position to clearly define this business driver. The World Bank (2010) intangible wealth, an amalgam of human and institutional capital, is by far the largest share of total wealth in virtually all countries, and that growth in intangible assets between 1995 and 2005 accounted for nearly $100 \%$ of the increase in wealth in sub-Saharan Africa, Eastern Europe and Central Asia. Because of the immense importance to business organizations and their increasing importance to non-business organizations, intangibles and knowledge-based assets need to be identified for purposes of valuing and management. It is the contention of Kaplan and Norton (2004) that "employees' skills, IT systems, and organizational cultures are worthy far more to many companies than their tangible assets." Kaplan and Norton further argue that "unlike financial and physical assets, intangible assets are hard for competitors to imitate, which makes them a powerful source of sustainable competitive advantage."

As yet, there is no evidence that in sub-Saharan Africa, intangible and knowledge-based assets are being managed like the traditional factors of labour, capital and raw materials. This is despite the World Bank's (20I0) findings that between 1995 and 2005, intangible assets accounted for nearly $100 \%$ of the increase in wealth creation in sub-Saharan Africa. Very few business and non-profit organizations have established positions specifically charged with managing intangible and knowledge-based assets. The nature of the global economy has changed so much that Teece (2000) suggests that fundamental changes have been wrought in the global economy which are continuously changing the basis of firm level competitive advantage, together with the functions of management. Because of the changes which have been wrought on the global economy, business and non-profit organizations should look beyond managing the traditional factors of production. Hall (1992; 1993) established that many Chief Executive Officers (CEOs) believe that the three most important intangible (off-balance sheet) resources are Reputation, Employee Know-how and Organizational Culture. In the emerging knowledge economy, both profit-making and non-profit organizations should devise and design managerial techniques specifically meant for managing intangible and knowledge-based assets.

This article has the objectives of:

- underscoring the strategic importance of identifying knowledge-based and intangible assets in sub-Saharan Africa;

- examining the performance of knowledge-based and intangible assets in innovation in a knowledge economy;

- finding out the role of intangible assets in generating competitiveness, economic growth and innovation in sub-Saharan Africa; and

- assessing how knowledge workers are becoming the dominant factor in the knowledge economy.

SA Jnl Libs \& Info Sci 20II, 77(2) 


\section{Data collection methodology}

This study adopted two major approaches to data-gathering in order to establish the strategic importance of identifying knowledge-based and intangible assets in sub-Saharan Africa. First, a thorough literature was conducted to have a clear understanding of the nature of knowledge-based and intangible assets and the role of such assets in generating competitiveness, economic growth and innovation in the emerging knowledge economies of sub-Saharan Africa. Secondly, the author used his own understanding of the nature of knowledge-based and intangible assets, and the nature of the knowledge economy to inform the study.

\section{The nature of knowledge-based and intangible assets}

It is in the opinion of Andreou, Green and Stankosky (2007) that intangible assets have been identified as the most critical resource of today's business enterprise even though most business organizations are not in a position to clearly define this business driver. The management of intangible assets can be tricky because as yet, there are not universally accepted methods of measuring their value. Flignor and Orozco (n.d.) cite Sir William Thompson, Lord Kelvin (I824-1907) as saying thus "When you measure what you are speaking about and express it in numbers, you know something about it, but when you cannot (or do not) measure it, when you cannot (or do not) express it in numbers, then your knowledge is of a meager and unsatisfactory kind." Intangible assets are said to refer to knowledge and skills (people's know-how) largely stored in the minds of people (Nelson \& Winte, 1982; Itami 1984) which cannot be easily codified or even transferred to other agents. This is because such assets are considered to have an important tacit component (Polanyi 1958; Lazaric \& Marengo 2000).

Diefenbach (2006) identifies a rather unique characteristic of intangible resources - which is that the stock of intangible resources can increase while being used. For example, to use knowledge in a conversation and further it as information to another person leads often to the result that the amount (and/or the quality) of knowledge has increased probably for both parties. This characteristic - a (possible) increase while being used - might be seen as "the" decisive criterion of demarcation against tangible assets. The three criteria of an intangible asset include identifiability, control (power to obtain benefits from the asset), and future economic benefits (such as revenues or reduced future costs). Taking the general idea and all three criteria together, Diefennbach defines intangible resources as:

An intangible resource is everything of immaterial existence, which is used or potentially usable for whatever

purpose, which is renewable after use, and which not only decreases, but can remain or increase in quantity and/or quality while being used. (Diefenbach 2006: 409)

A Swedish financial services company by the name of Skandia AFS is reputed to be one of the first to report the "intangibles" as business assets. In 1995, a supplement to the company's annual report used for the first time the word "IC", instead of the accounting term "intangible assets" (Edvinsson and Malone, 1997). The Skandia Value Scheme which is shown in Figure I was developed by Edvinsson in 1993. It interprets the market value of a firm as comprising the financial capital (inclusive of all tangible assets) and the IC (non-financial value). It further divides IC into structural capital (SC) and human capital (HC). SC includes customer and organizational capital that relates to the external and the internal focus of SC. Customer capital (CC) represents the external focus of the company and is a valuation of the customer relationships. Organizational capital consists of innovation and process capital. Process capital represents the know-how (for example, manuals and best practices) in the company. Innovation capital is that which creates success in the future and includes intellectual assets and intellectual property, both of which are intangible.

In categorizing organizational resources, Stewart (1997) uses a different conceptual scheme and divides intellectual capital (IC) into three basic forms: human capital (HC), structural capital (SC), and customer capital (CC). Human capital is the accumulated capabilities of individuals charged with providing customer solutions. Structural capital refers to the capabilities of the organization to meet market requirements. Unlike human capital, structural capital can be formally captured and embedded. Customer capital points to the extent and intensity of the organization's relationships with customers. The three types are interrelated - each one positively or negatively affecting the other. Figure 2 shows the components of intellectual capital espoused by Stewart (1997). 


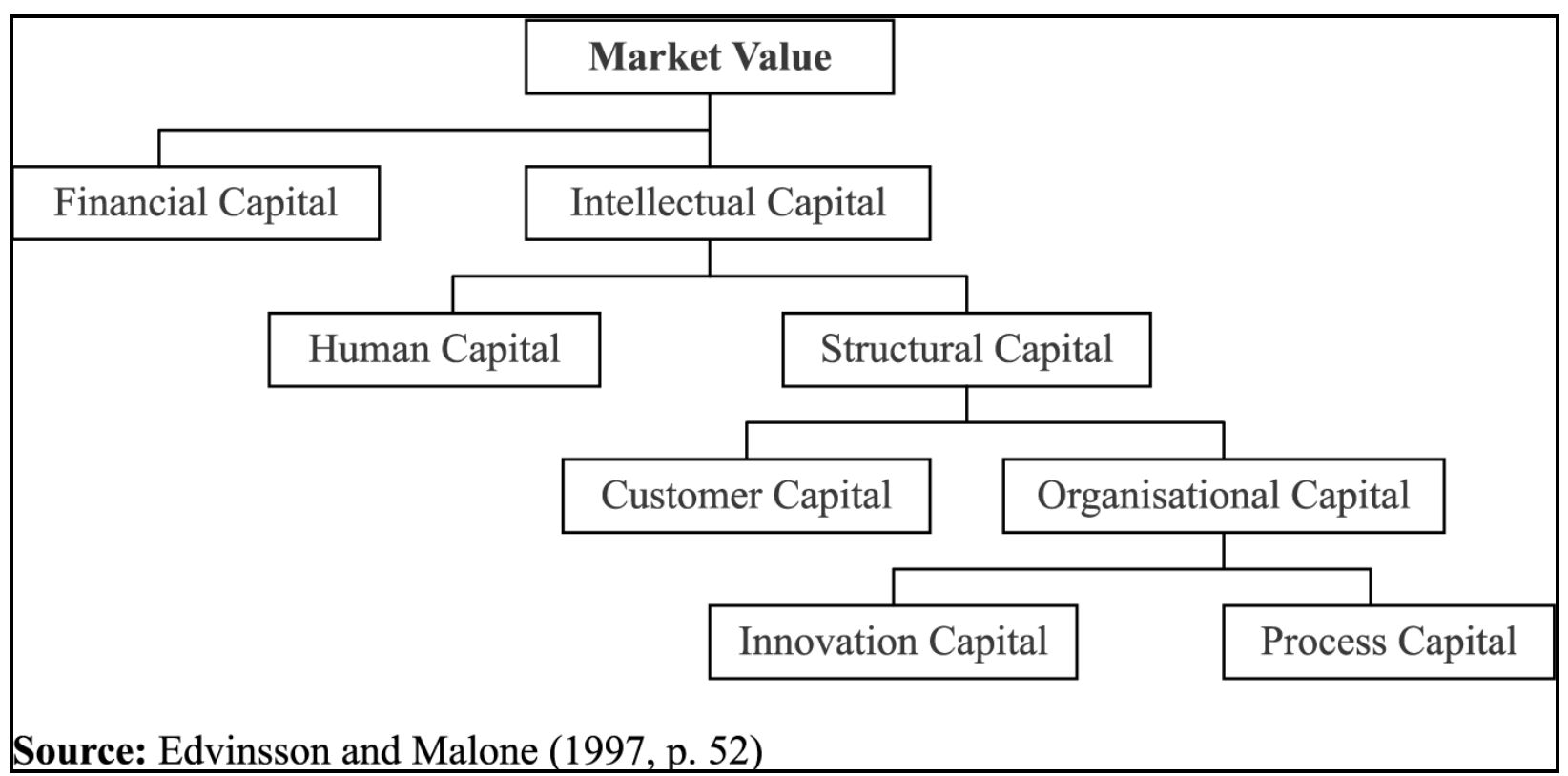

Figure 1 The Skandia Value Scheme

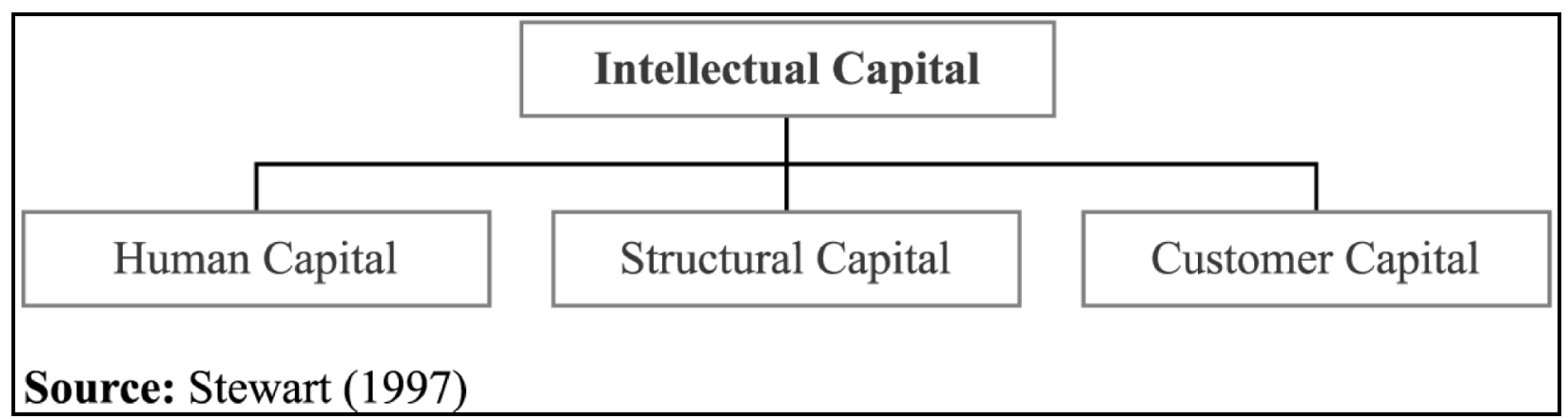

Figure 2 Elements of intellectual capital

\section{The concept of a knowledge economy}

The "knowledge economy" is a recent phrase in management literature that denotes the importance of knowledge management in economic growth and sustainability. To understand why knowledge management has grown in importance in recent years, it is necessary to look at the economic context within which it is developing (Morrow 200I). Knowledge economy involves consideration of networked economy and the role of information and knowledge in economic performance.

According to Morrow (200I), networked and/or knowledge economy share common themes: (I) that developments in technology, especially information and communication technologies, are altering the economic bases of, at least developed countries; (2) that the key industries in this new economy are knowledge-intensive and heavily dependent on knowledge workers; (3) as a consequence of globalization, competitive advantage between nations rests on the extent to which they can develop their knowledge industries and knowledge workers; and (4) that the knowledge component of all industries is increasing and that value-added comes from the substituting physical resources with intangibles.

Davenport and Prusak (1998) emphasize that production of ideas and not goods is the source of economic growth. Morrow (200I) credits technology facilitating growth in that it allows ideas in the form of techniques, research results, protocols, etc. to be globally distributed. Technology has also enabled industries to globalize and relocate to take advantage of low-cost, low-skilled labour elsewhere while still coordinating and controlling operations from home base. 
Technology has further facilitated the development of a new range of industries based primarily on the production of information and knowledge.

Skyrme (1999) identifies some characteristics of a knowledge economy:

- Every industry is becoming more knowledge intensive;

- Industries are using knowledge to produce "smart products and services" which command premium prices;

- The market value of most business organizations is several times higher than the value of their physical assets as recorded in their balance sheets; and

- Trade in intangibles has come to mean that there is a growing range of intangibles that are traded in their own right. (Skyrme 1999:12-13).

Tissen, Andriessen and Deprez (1998) identify certain signs of the presence of a knowledge economy as:

- Growth of technology-driven companies, with a major knowledge component are outgrowing almost every other company;

- Many traditionally industrial companies - those designed and built to produce physical products - are being forced to produce and provide knowledge products and services;

- Knowledge workers are becoming the dominant factor in the Knowledge Economy, just as farmers were the dominant factor in the agricultural age, and as workers were in the industrial age;

- The increase in complexity has resulted in a growing need for specialization and this trend will only increase because the knowledge sector is where the jobs are;

- Employment opportunities in other sectors are decreasing in line with the increase in knowledge services; and

- Industrial-based economies are declining and in many countries, services are providing a significantly larger share of Gross National Product) GNP. (Tissen, Andriessen \& Deprez 1998)

In a knowledge economy, the question should not be whether knowledge-based and intangible assets are tradable. Instead, the question should be how to identify knowledge-based and intangible assets purposes of trade, measurement of value and management of such assets.

Other characteristics of a knowledge-based economy according to Andriessen (2004) include:

- Knowledge replaces labour and capital as fundamental resources in production and intangible assets create a substantial part of the value added of companies;

- The knowledge content of the products and services is growing rapidly;

- The concept of ownership of resources has changed: knowledge resides in the heads of employees of organizations; and

- The organizations have changed and the management of intangible resources is different from tangible or financial resources.

4.1 Knowledge workers in the knowledge economy

In the knowledge economy, there is a category of workers who have come to be identified as "knowledge workers."

Who are the knowledge workers and what is the nature of their work? Gurteen (2006) defines knowledge workers thus:

Knowledge workers are those people who have taken responsibility for their work lives. They continually strive to understand the world about them and modify their work practices and behaviours to better meet their personal and organisational objectives. No one tells them what to do. They do not take 'no' for an answer. They are self motivated.

Gurteen (2006) outlines the characteristics of knowledge workers as:

- Workers who take responsibility for their work;

- Workers who cannot be coerced,

- Workers who cannot be bribed, manipulated or rewarded

- No amount of money or fancy technology may 'incentivize' knowledge workers to do a better job;

- Knowledge workers see the benefits of working differently for themselves;

- They are not 'wage slaves'- they take responsibility for their work and drive improvement.

In a knowledge economy, more and more work is knowledge-based (Drucker 1993). Drucker (1993) argues that even manufacturing jobs in a knowledge economy require professional expertise and mastery of a large body of knowledge. Most workers in the knowledge economy in effect are knowledge workers. This same trend towards more knowledge workers is present in service industries, not-for-profits organizations and in government. Drucker (2003) suggests that one-third of all jobs in a knowledge economy are filled by the highly productive group he calls knowledge workers. 
Knowledge work involves information gathering, imagination, experiment, discovery, and integration of new knowledge with larger systems (Myers 1996). With this nature of knowledge work, Myers argues that bosses cannot order about knowledge workers like the ditch diggers or assembly-line bolt turners of the yore. Myers further contends that if knowledge workers are any good at all, they soon learn more about what they are doing on a specific project than their bosses can. Knowledge work inherently has a large component of self-direction and team and may be hampered by remote control from distant bosses. As we move further into the knowledge economy and beyond bureaucracy, ways should be found to organize so that all work is knowledge-based, bringing everyone's native intelligence and collaborative abilities to bear on constantly changing ways of achieving shared goals.

\subsection{The sub-Saharan Africa region}

Sub-Saharan Africa refers to the countries of the African continent south of the Sahara desert. Geographically, the demarcation line is the southern edge of the Sahara desert. Some countries such as Chad, Mali, Sudan, Niger and Mauritania belong both to the Saharan desert region and sub-Saharan Africa region.

According to the World Bank (20II) development indicators, the sub-Saharan Africa region ranks lowest in every development indicator. Table I shows how the World Bank ranks the sub-Saharan in terms of World Development Indicators. Compared with other regions, sub-Saharan Africa has the lowest Gross National Income per capita (US\$ 2,05 I.2) as 2009, the lowest life expectancy at birth (52.5 years), the lowest primary school completion rate (60\%) of the relevant age, lowest rate of access to improved water source (60\%), and the lowest internet per 100 people (4.4).

Table I Regional fact sheet from the world development indicators (WDI) 20I I

\begin{tabular}{|c|c|c|c|c|c|}
\hline & & 2000 & 2001 & 2008 & 2009 \\
\hline $\begin{array}{l}\text { Sub-Saharan Africa } \\
\text { (developing only) }\end{array}$ & GNI per capita, PPP (current international \$) & $1,300.3$ & $1,354.4$ & $2,018.8$ & $2,05 \mid .2$ \\
\hline $\begin{array}{l}\text { Sub-Saharan Africa } \\
\text { (developing only) }\end{array}$ & Population, total (in millions) & 671.8 & 689.2 & 819.4 & 839.6 \\
\hline $\begin{array}{l}\text { Sub-Saharan Africa } \\
\text { (developing only) }\end{array}$ & GDP (current US\$) (in millions) & $342,127.2$ & $332,097.2$ & $993,507.8$ & $945,922.8$ \\
\hline $\begin{array}{l}\text { Sub-Saharan Africa } \\
\text { (developing only) }\end{array}$ & GDP growth (annual \%) & 3.7 & 3.5 & 5.0 & 1.7 \\
\hline $\begin{array}{l}\text { Sub-Saharan Africa } \\
\text { (developing only) }\end{array}$ & Life expectancy at birth, total (years) & 50.1 & 50.2 & 52.1 & 52.5 \\
\hline Sub-Saharan Africa & Primary school completion (percentage of the population) & & & & 60 \\
\hline Sub-Saharan Africa & Improved water source (percentage) & & & & 60 \\
\hline Sub-Saharan Africa & Internet access per 100 people & & & & 4.4 \\
\hline
\end{tabular}

Source: 201 I World Development Indicators Database, World Bank, April 201 I.

\section{Identification of knowledge-based and intangible assets and the capturing of their value}

It is important to identify knowledge-based and intangible assets as they are invisible and intangible. Because of their nature, knowledge-based and intangible assets are not captured very well by any of the traditional measures, accounting or otherwise, that corporations master in their everyday operations (Hauser \& Katz 1998). Because of the nature of knowledge-based and intangible assets, managers may run the risk of 'forgetting' that the knowledge-based and intangible assets are there. Managers may also underestimate the value and contribution of knowledge-based and intangible assets of an organization. Decisions may thus be made which in the long-term might prove harmful and costly precisely because of the damage the 'intangible asset stock' of the organization may cause. Wrong decisions may be made if decision makers of an organization ignore or do not make use of the knowledge-based and intangible assets available within the organization.

It is one thing to invest in intangible assets and it is another thing understanding and accounting adequately for investments in intangibles. Not understanding and consequently not accounting properly for investments in intangibles can have negative consequences. Blair and Wallman (200I) believe that failure to account adequately for investments in intangibles results in understatement of Gross Domestic Product (GDP), of corporate profits, and of personal savings because accounting systems which treat any investments intangible assets as expenses, resulting in overstating the cost of producing current output. Blair and Wallman (200I) further argue that failure to understand the role of intangible assets in the aggregate economy will repeatedly lead to misdiagnoses of economic problems and inappropriate policy responses.

SA JnI Libs \& Info Sci 20I I, 77(2) 
5.1 Intangible assets and the property rights

One important characteristic of an asset or a resource is that it should be owned by a person, a community or an organization. Lack of ability to identify intangible assets may deny countries and organizations in sub-Saharan Africa revenues which may accrue from such assets. In the property rights view, a firm is considered to be a bundle of rights to control the resources it owns. Farok (200I) cites Williamson (199I) as contending that a central position of this view is that "economic performance is largely determined by the way in which property rights are defined." A resource or an asset has several other attributes that, under appropriate circumstances, may enable the use of that resource to generate rents or wealth for its owner. Examples of the attributes of a resource or asset include the resource being unique or ubiquitous, attributes which enable synergistic uses of the resource in combination with other complementary assets. Intangible assets have the attributes of being unique, they can be used in combination with other complementary resources to generate wealth and they are usually owned by a particular individual, a community or by an organization. Because of the apparent strategic importance intangible assets, organizations and countries in sub-Saharan Africa need to devise ways of properly identifying and/or accounting for the kind of intangible assets they own. The control over these attributes (i.e. the right to use the resources, the right to appropriate the returns from the resources, and the right to transfer the location) are called property rights (Furubotten \& Pejovich 1974).

Property rights over an asset, whether intangible or physical can be considered the source of wealth associated with the asset in that they provide the necessary conditions for value-creating decisions to be made concerning the asset. The ability of an organization or firm to make such decisions essentially depends on various rights identified and highlighted by the property rights approach. According to Farok (200I), such property rights include:

- The right to exclude others from use of the asset - one cannot exclude others from use of an asset if one does not have the ability to identify that asset.

- The right to combine the assets with other types of assets - it is not possible to combine an asset with other assets if the asset is not identifiable.

- The right to modify the assets - an asset can only be modified if it is identified.

- The right to transfer the asset- It is not practicable to transfer an asset that is not well identified.

It is true that none of these rights may individually be sufficient to create value. However, exercising various rights in combination may lead to creation of value.

\subsection{Appropriation of returns from knowledge-based and intangible assets}

Assets, whether tangible or intangible are supposed to generate some form of income or wealth for the owner/s. It is important to identify knowledge-based and intangible assets for purposes of appropriating returns or rent for that matter. Income approaches are based around the concept that an asset's worth is equal to the present value of the future returns the asset is expected to generate. This involves forecasting the entity or asset's ability to generate cash and adjusting the future income streams to today's value by discounting for risk. Forbes (2008) suggests a number of income-based methods as being ideal for appropriation of returns from knowledge-based and intangible assets. The methods include royalty relief, intangible asset contribution and multiple-period excess earnings.

\subsection{Intangible assets and taxation issues}

The failure to understand the role of intangible assets in the aggregate economy will lead repeatedly to misdiagnoses of economic problems and inappropriate policy responses (Blair \& Wallman 200I). Blair and Wallman think there is good reason to believe that the failure to account adequately for investments in intangibles results in understatement of GDP, of corporate profits, and even of personal savings. This is because current accounting systems treat investments in intangibles as expenses, thereby overstating the costs of producing current output. Intangible assets are subject to taxation and if their value is not well understood, it is possible that the assets may either be under taxed or overtaxed by tax authorities. It is possible that the failure to account adequately for investments in intangibles results in understatement of GDP and corporate profits in sub-Saharan Africa. Sun-Saharan African countries need to expand their tax base so as to collect adequate revenues for financing services offered by the governments rather than depending on aid from outside for financing such services.

Abdullah (2004) is of the opinion that tax authorities and multinational companies have been facing great challenges in dealing with transfer pricing of intangible assts. The challenges Abdullah (2004) identifies include:

- The globalization of multinational companies and the rapid expansion in the cross-border business transactions of services and technology;

- The shift from a predominantly manufacturing economy to a service economy spurred by innovative technology; and

- The increasing importance of intangibles in generating wealth. 
Levey (200I) argues that in the $2 I^{\text {st }}$ century, the significant and fast development of e-commerce and service companies' paradigms in proportion to the bricks-and-motor activities pushes tax authorities around the world to continue the attack of transfer pricing practices of multinational companies by issuing new transfer pricing regulations and adjusting old ones to meet the e-commerce challenges. Transfer pricing regulations may only be streamlined if the value of intangible assets is well understood by both tax authorizes and those who invest in intangible assets.

Globalization has resulted in the presence of multinational companies conducting businesses in all countries of the world. Most developing countries, which are largely excluded from the knowledge economy, have erratic tax regimes. The tax regimes in most developing countries lack expertise to identify and determine the true value of knowledge-based and intangible assets. The rates of taxation on investments are supposed to be determined by the investments' true or close to true value. Multinational companies trading in developing countries may not necessarily reveal the true value of their intangible assets to the tax authorities of such countries. Depending on whether or not the intangible assets are properly identified in a country, they may not be taxed at all or at best they may be taxed at lower tax rates than their true value, resulting in understatement of the GDP (Blair \& Wallman 200I).

Some countries have documented foreign transfer pricing tax rules. Abdullah (2004) urges that it is very important for multinational companies trading in foreign countries to note that transfer pricing tax rules in France, Mexico, the Netherlands, and the United Kingdom may impose penalties of up to 100 percent of the amount of tax determined by tax authorities to be underpaid as a result of a tax audit examination or if tax payers may have acted fraudulently or negligently. For any related party transfer pricing fraud, or substantial valuation misstatement, Canada imposes penalties of up to 10 percent, Japan up to 35 percent, and the USA between 20 and 40 percent. Germany does not specify penalty rates for violations of transfer pricing tax rules. In most developing countries, there is lack of documentation of transfer pricing tax rules for intangible assets. There is no evidence that any country in sub-Saharan Africa specifies penalty rates for violations of transfer pricing tax rules for intangible assets. Practically, intangible assets are transferred from other countries to sub-Saharan Africa on a daily basis.

\section{Intangible assets and competitive advantage}

Information, knowledge, and other intangibles now power economic prosperity and wealth creation (Ellis 2009). Ellis further argues that intangible assets-worker skills and know-how, informal relationships that feed creativity and new ideas, high-performance work organizations, formal intellectual property, and brand names-are the new keys to competitive advantage. Intangibles and information have been known to drive innovation through a combination of formal research and informal creativity. These elements may be harnessed to fuel the productivity gains and process improvements that may enhance prosperity in sub-Saharan Africa in the 2 I st century.

In recent years the concept of competitive advantage has taken center stage in discussions of business strategy. Statements about competitive advantage abound, but a precise definition is elusive (Rumelt 2003). In reviewing the use of the term competitive advantage in the strategy literature, the common theme is value creation. However, there is not much agreement on value to who, and when. This may make the valuing of intangible assets even more unrealistic in subSaharan Africa where many organizations and governments do not appreciate the importance of such assets. According to Rumelt (2003), there are three schools of thought on value and value creation. One school of thought has it that value is created by favorable terms of trade in product markets. That is, sales in which revenues exceed costs. However, scrutiny of the concept of "cost" quickly reveals problems. What is the "cost" of a scarce resource? A second school of thought holds that advantage is revealed by "super-normal" returns. Again, questions quickly arise. Internal returns are normally measured by some type of market-book ratio. Such ratios include return on capitall, return on assets, marketto-book value, and Tobin's Q. Given such a measure, are supernormal returns "super" relative to the expectations of owners, the economy as a whole, or the rest of the industry? A third school of thought ties advantage to stock market performance. According to financial economics, superior stock market performance stems from surprising increases in expectations.

Saloner, Shepard and Podolny (200I) think that "most forms of competitive advantage mean either that a firm can produce some service or product that its customers value than those produced by competitors or that it can produce its service or product at a lower cost than its competitors."They also say that "In order to prosper, the firm must also be able to capture the value it creates. In order to create and capture value the firm must have a sustainable competitive advantage. Dierickx and Cool (1989) argue that competitive advantage is not obtainable from freely tradable assets "if a privileged product market position is achieved or protected by the deployment of scarce assets, it is necessary to account for the opportunity cost of those assets. Many inputs required to implement a strategy may be acquired in corresponding input markets. In those cases, market prices are indeed useful to evaluate the opportunity cost of deploying those assets in product markets. However, the deployment of such assets does not entail a sustainable competitive advantage, 
precisely because they are freely tradable." Intangible assets may be looked upon as those assets that are not freely tradable.

Resources or assets of an organization are looked upon as antecedents of any competitive advantage that an organization may enjoy. Not much evidence is available on the competitive advantage of intangible assets. The initial studies on resources as antecedents of a competitive advantage were conducted by researchers within the classical resource-based school (Penrose 1959; Wernerfelt 1984). While in the early stages studies focused on both tangible and intangible resources, towards the end of the 20th century the term "resources" started becoming increasingly replaced by more intangibles-related terms such as core competencies (Prahalad \& Hamel 1990), knowledge (Nonaka \& Takeuchi 1995; Grant 1997) and intellectual capital (Edvinsson \& Malone 1997). In this article, there is an attempt to show that intangible assets can be relied on to generate value and competitive advantage in sub-Saharan Africa. However, it should be noted that intangible resources should not be relied upon to generate value and competitive advantage in isolation from tangible resources.

According to the resource-based view (RBV), assets, skills and capabilities create value for the firm that leads to a sustainable competitive advantage and superior financial performance (Barney 199I). Resources used to create a competitive advantage are categorized as tangible (e.g., financial assets, capital, production capability, etc.) or intangible assets (e.g., intellectual property, trade secrets, corporate reputation, culture, employee know-how, etc.) (Hall 1993). These intangible resources create value and meet the following conditions:

- It is valuable due to its ability to add financial value to the firm (sources of differentiation;

- It is rare -meaning only some firms have it;

- It is imperfectly imitable by other organizations; and

- There are no readily available substitutes (Barney, 1986; Barney, 1991; Rao, 1994).

Culture and reputation are considered intangible assets because each adds value through differentiation, it is rare, difficult to imitate, and without substitution (Barney 1991; Hall 1993; Fombrun 1996; Porter 1996; Roberts \& Dowling 2002; Kaplan \& Norton 2004). In a survey of business organizations, it was found that corporate reputation is rated as the most important intangible asset contributing to business success because it is the "product of years of demonstrated superior competence, it is a fragile resource; it takes time to create, it cannot be bought, and it can be damaged easily (Hall 1993)". In the same study, Hall (1993) found out that culture was rated as the fourth most important intangible asset, after product reputation (rated number 2) and employee know-how (rated number 3), since culture afforded the ability to manage change, innovate, create team work and a participative management style, and the perception of high quality standards and customer service.

Intangible assets are characterized as more influential than tangible assets because they are more likely to meet Barney's (1991) four conditions (listed above). Hall (1992) refers to intangible assets as the "feedstock" of capability differentials essential for a sustainable competitive advantage. Kaplan and Norton (2004) apply this perspective and develop a "strategic map" to demonstrate how intangible assets, like culture, may be used to attain a strategic advantage and higher performance outcomes in an organization.

The RBV also proposes that an organization's performance will be determined by the distinct bundles of resources or an asset a firm has (Barney 1991). These bundles generate the firm's sustainable competitive position by its "complex combination of organizational elements" and not necessarily by any single element, regardless of how important an element may be (Carmeli \& Tishler, 2004). This is consistent with Porter (1996), who shows how a sustainable competitive advantage results from a tight strategic fit among a highly integrated set of tangible and intangible relationships.

\section{The role of knowledge-based and intangible assets in innovation}

Innovation is a multi-stage process whereby organizations transform ideas into new/improved products, service or processes, in order to advance, compete and differentiate themselves successfully in their marketplace (Baregheh, Rowley \& Sambrook 2009). Innovation concerns processes of learning and discovery about new products, new production processes and new forms of economic organization, about which, ex ante, economic actors often possess only rather unstructured beliefs on some unexploited opportunities, and which, ex post, are generally checked and selected, in non centrally planned economies, by some competitive interactions, of whatever form in product market (Dosi 1990). One may argue that innovation plays a major role in generating competitive advantage not only for organizations, but also for countries and regions. Innovation is recognized to play a central role in creating value and sustaining competitive advantage. 
In sub-Saharan Africa, it may be perceived that innovation is confined to business organizations. However, the significance of innovation should not necessarily be confined to business organizations. The USA government has in place an Advisory Committee on Measuring Innovation in the $21^{\text {st }}$ Century American Economy (2008), and in the UK there has been widespread and ongoing acknowledgement of the importance of innovation. In 2003, the UK Department of Trade commented on the link between continuous innovation and jobs, profit and standards of living: "If UK-based companies fail to innovate, jobs and profits will suffer, and our standard of living will fall compared with other countries”. More recently, the UK's Department for Innovation Universities and Skills (2008) commented on the wider implications of innovation in the face of globalization and environmental challenges by highlighting the importance of all types of innovation in creating and maintaining competencies and responding to environmental and demographic restrictions. There is agreement that in order to both sustain their competitive position and to strengthen it, organizations and economies must innovate and promote innovation. Innovation should be made a key policy and strategic issue in subSaharan Africa for purposes of economic growth, creation of jobs, creating and maintaining competencies and responding to environmental and demographic dynamics.

According to the UK's Department for Innovation Universities and Skills (2008) most new ideas do not come as a flash of inspiration to a lone genius inventor; they come from how people create, combine and share their ideas. A country's capacity to unlock and harness the talent, energy and imagination of all individuals is crucial to making innovation stronger and more sustainable. The effects of innovative people are self-reinforcing: innovative businesses are attracted to highly skilled and creative workforces and, in turn, innovative people are drawn towards exciting and challenging career opportunities. Furthermore, innovative people generate new ideas that require skilled people to implement and exploit them.

This flow of ideas brings special advantages to places that have strong capacity to absorb ideas and talent from elsewhere and recombine them to create new knowledge and opportunities. High "absorptive capacities" help places channel global flows into their local economies and become even more connected to the global economy in return. Countries in the sub-Saharan Africa Region are not known to have high absorptive capacities to absorb ideas and talent from elsewhere and recombine them to create new knowledge and opportunities.

Jarboe, Furrow and Athena Alliance (2009) are of the opinion that all countries account for investment in tangible assets in their gross domestic product (GDP) statistics, but no country currently includes a comprehensive estimate of business investment in intangible assets in their official accounts. Most economists agree, however, that intangible assets-which represent an important input into the innovative process-are critical components of the modern economy. In the United States, some economists have suggested that investment in intangible assets now roughly equals investment in tangible assets. Understanding the role of intangible assets - and thus the role of innovative activity in general-is critical to understanding the modern economy. In sub-Saharan Africa, there is very little on the role of intangible assets in innovation in the available literature.

Jarboe, Furrow and Athena Alliance (2009) further argue that the innovation process leads to the creation of economically useful knowledge that exists separately from either people or tangibles, such as equipment or structures. This economically useful knowledge is an intangible that is an output of a productive process as well as an input into the creation of new output. By identifying measures of this knowledge, measuring them using national accounting, and incorporating them into a growth-accounting framework, one can begin to develop a comprehensive set of statistics to better understand innovation as a driver of economic growth.

\section{The regional and geographical dimensions of innovation}

According to Moreno, Paci and Usai (2006), intangible assets are also an important consideration for clusters and the geography of firms, as well as regional linkages. Analysis shows that there are important differences in the inventive performance of regions in economies, as measured by indicators for one of the key types of intangible assets (i.e. patents). Inventive performance is shown to be particularly concentrated in certain regions of continental Europe, North America and Japan. Sub-Saharan Africa is almost completely excluded from inventive performance (see Figure 3). The development of inventive activities in countries usually takes place in a small number of regions. There are linkages both between geographical areas and between firms as a result of the flow and transfer of intellectual assets and knowledge spillovers. Geography matters for the spatial distribution of intangible assets and innovation activities in particular, as knowledge flows and specific skills often require proximity to be fully exploited.

Preliminary results from work pioneering a new OECD regional database (Usai et al., 2008) indicate that the regional distribution of innovation is skewed, especially in Europe. They confirm that highly inventive regions tend to cluster together. There are linkages both between geographical areas and between firms as a result of the flow and transfer of intellectual assets and knowledge spillovers. Moreover, the geography of innovation is influenced by factors such as 
regional and local governance, infrastructure and factor endowments (e.g. skilled labour), alongside national factors such as macroeconomic conditions and policy frameworks, specifically on competition, R\&D, and intellectual property right (IPR) protection all of which are rather weak in the sub-Saharan Africa region. Cross-country differences point to the importance of national innovation systems. The results also indicate the importance for innovation of linkages within firms across regions. At the same time, the most inventive regions tend to have relatively more multi-regional firms among their innovative firms. It is important to arrive at a better understanding of these processes, in order to maximize the returns to innovation and optimizing the effects and efficiency of innovation policy.

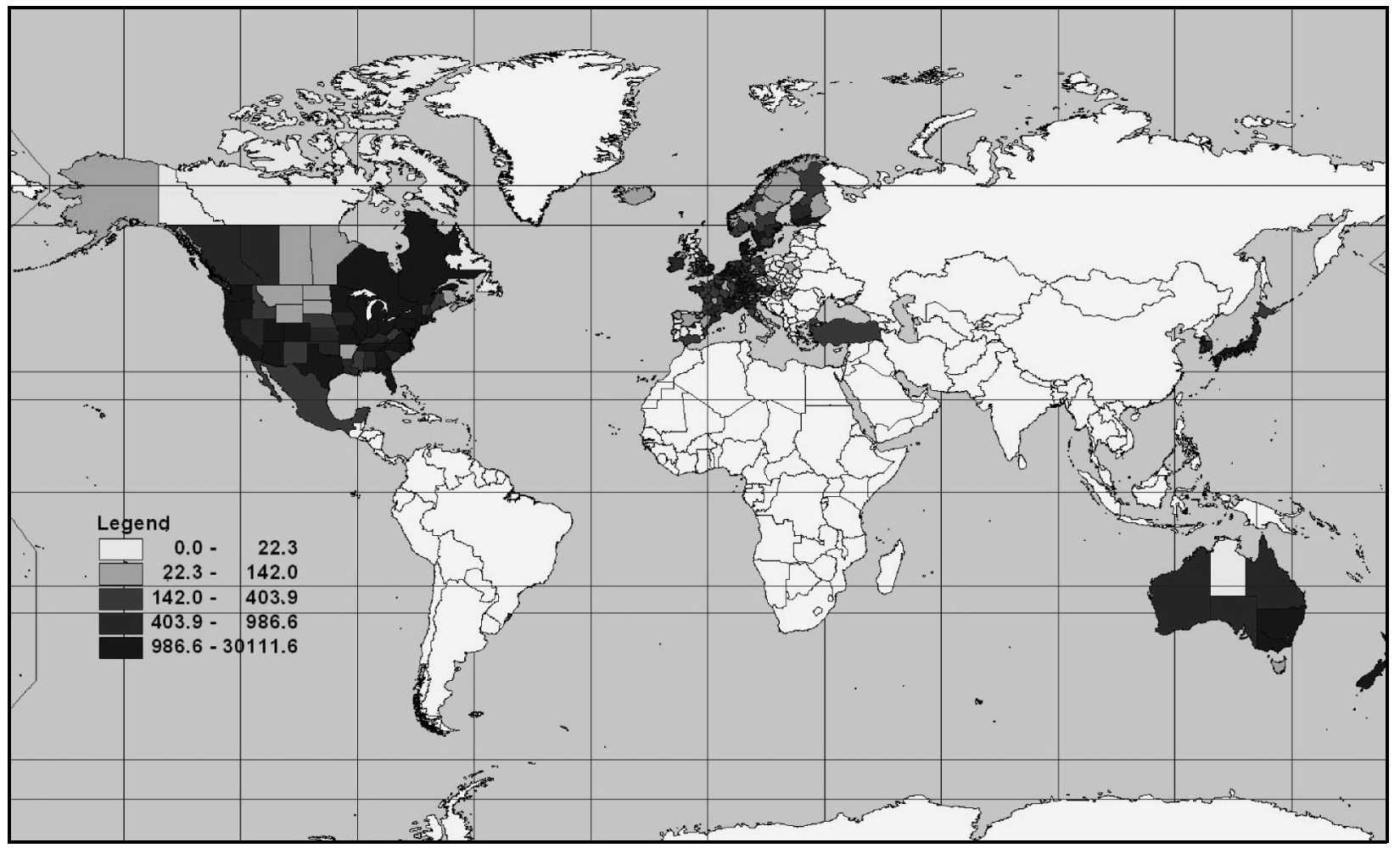

Source: OECD Regional Database.

Figure 3 Global Inventive performance 2000-2004

Per capita invention performances in different regions of the world 2000-2004 indicate as follows:

- Sub-Saharan Africa, the larger Africa: $0.0-22.3$

- Asia:

- South America:

- Some parts of N. America and Europe: 22.3-142.0

- Some parts of N. America and Europe: 142.0-403.9

- Some regions of N. America and Europe: 403.9-986.6

- Some regions of N. America, Australia and Europe: 986.6-30III.6

Usai et el., (2008) state that the inventive performance of a region can be related to the share of skilled workers as the concentration of skilled workers in a region should enable externalities to materialize since direct communication enables flows of information and tacit knowledge. At the same time such a concentration can give rise to important pecuniary externalities in the job market for talented and experienced workers and researchers. Sub-Saharan Africa faces the challenge of losing skilled workers and experienced researchers to regions and countries where conditions of inventing are more favourable. The density of economic exchanges and contacts is assumed to act as a catalyst for agglomeration effects. Innovation systems have been found to matter for innovation performance at the aggregate level and regional innovation institutions and strategies are likely similarly important in stimulating and diffusing innovation. Regional innovation institutions in sub-Saharan Africa are not known for remarkable inventions although they have the potential. 
Because of its geographical location, sub-Saharan Africa does not benefit from spillovers of innovations and knowledge from other regions which lead in inventions. The production of knowledge in a region may depend not only on its own research efforts, but also on the knowledge stock available in the whole economy and on its ability to exploit it. Many factors, including those external to the region, can have an impact on technological activity, such as trade and investment flows and common markets for skilled labour and final goods.

\section{Creation of value from intangible assets}

Can firms in sub-Saharan Africa create value from knowledge-based and intangible assets? According to the OECD (2008) the ability to create value from intellectual assets at the firm level is highly contingent on the management capabilities in individual firms and the implementation of appropriate business strategies. There are essentially three ways in which value can be created at the firm level: I) by increasing the consumer surplus; 2) by increasing the producer surplus; and 3) by increasing the stock market valuation of the firm. OECD (2008) further contends that work on the impact of research and development, patents, human capital and software shows that the average returns on investment in intellectual assets can be large. Many organizations in sub-Saharan Africa are government-owned and the primary objective of governmentowned organizations is to provide goods and services to members of the general public at affordable costs. Governmentowned organizations in sub-Saharan Africa don't look at research and development as a priority as they are not under any pressure to improve the quality of their goods and services. Many government-owned organizations in sub-Saharan Africa have for a long time enjoyed monopoly in the goods and services they provide. Such organizations do not invest in research and development and link their research findings to their business strategy. Such techniques are particularly important in competitive industries where innovative products rapidly become commodities through follow-on innovation and imitation. The ability of organizations to manage risks is also important, requiring systems of internal control and good information including with respect to intangible assets.

The increasing importance of intellectual assets for value creation is reflected in corporate expenditure, whereby investment in intangible assets appears to be approaching levels comparable to investment in tangibles. The OECD (2007) estimates that investments in intangible assets in some advanced economies amount to between $7.5 \%$ and $\mathrm{II} .7 \%$ of gross domestic product, depending on the country. Corrado et al., $(2005 ; 2006)$ estimated the annual investments in intangible assets by US businesses in the late 1990s, highlighting the growing importance of investment in intangibles (see Figure 4).

\section{— Intangible Investment \\ — Tangible Investment}

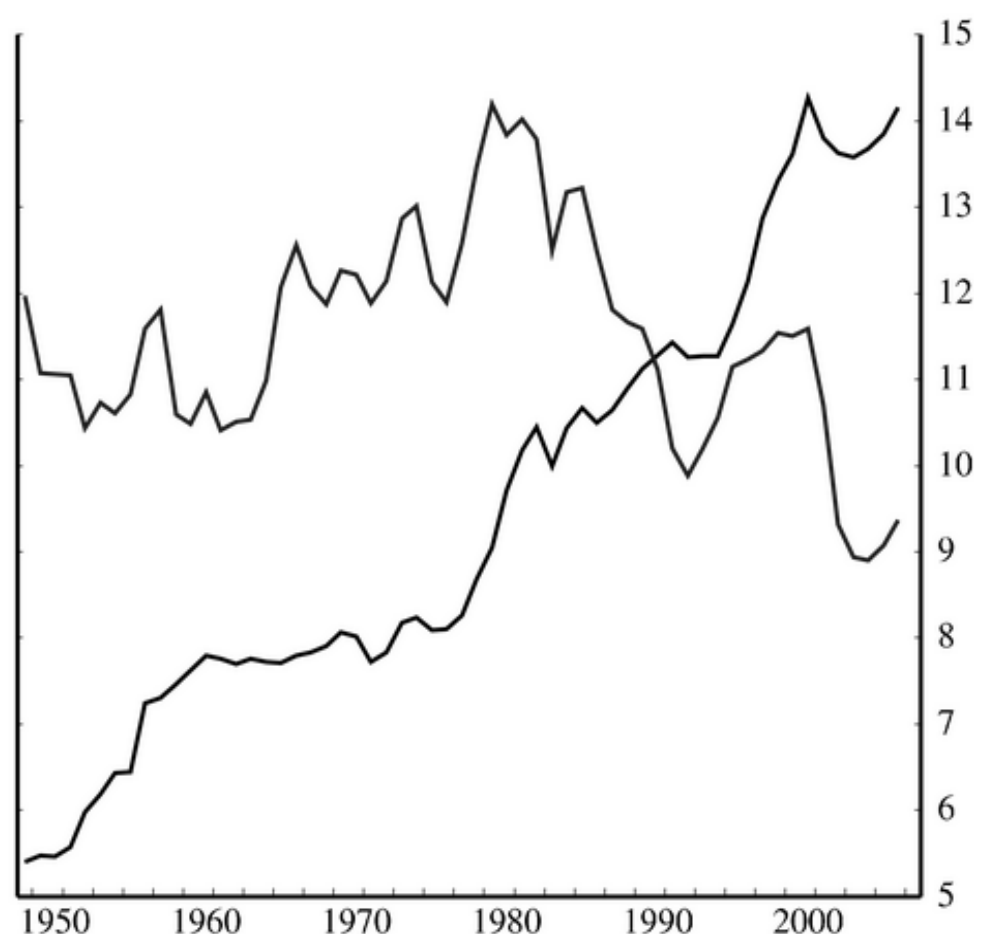

Figure 4 Business investment in the US, tangible and intangible investment (Ratio to business output) Source: Corrado et al., $(2005,2006)$ 


\section{Findings and discussion}

In the available literature, there are many issues pertaining to creating value from knowledge-based and/or intangible assets. Some of the most important issues include competent management, technical know-how, the geographical dimensions of innovation, which are largely influenced by factors such as regional and local governance, infrastructure and factor endowments (e.g. skilled labour), alongside national factors such as macroeconomic conditions and policy frameworks, specifically on competition, research and development, and intellectual property right protection. Crosscountry differences point to the importance of national innovation systems. The results also indicate the importance for innovation of linkages within firms across regions. At the same time, the most inventive regions tend to have relatively more multi-regional firms among their innovative firms. It is important to arrive at a better understanding of these processes, in order to maximize the returns to innovation and optimizing the effects and efficiency of innovation policy.

There are various types of "economies of agglomeration", related notably to the use of common resources by innovative actors. For instance, agglomerations benefit from positive "local externalities" such as lower communication, transportation costs and knowledge spillovers. Sub-Saharan Africa is far away from innovative actors who are mostly in North America, Western Europe and Austrasia. The local availability of skilled labour, of competitive firms and the presence of high quality publicly funded research (universities, public laboratories) have also been found to matter. Universities and public laboratories in sub-Saharan Africa are not well equipped for purposes of generating innovation. A problem for Africa as a whole, as it has been for China and India, is the hemorrhage of talent (Adams, King \& Hook 20 I0). Many of Africa's best students take their higher degrees at universities in Europe, Asia and North America. Too few of those who graduate with higher degrees from foreign universities return to Africa. The African Diaspora provides powerful intellectual input to the research achievements of other countries but returns less benefit to the countries of birth. Those who stay away from sub-Saharan Africa could be counted on to conduct research, innovate and come up with new inventions. That is at least in part because of a chronic lack of investment in facilities for research and teaching, a deficit that need to be remedied by governments in the sub-Saharan region. In its report, UNESCO (2007) stresses that science and technologies are critical not only to Africa's economic prosperity but also to such matters as food security, disease control, access to clean water, and environmental sustainability.

However, there is reason to believe that not everything is lost in sub-Saharan Africa. Basu, Calamitsis and Ghura (2000) reporting for the IMF argue thus:

Africa is the world's poorest continent. But for the first time in a generation - amid all the bad news - there is hope for change. An increasing number of countries in sub-Saharan Africa are showing signs of economic progress, reflecting the implementation of better economic policies and structural reforms. These countries have successfully cut domestic and external financial imbalances, enhancing economic efficiency. They have given greater priority to public spending on health care, education, and other basic social services. In addition, there has been a growing movement toward more open and participatory forms of government that encourage cooperation between the state and civil society (Basu, Calamitsis \& Ghura 2000).

Poor investment in education, social services and health care are some of the factors which discourage natives of subSaharan Africa from going back to their countries of birth after completing their higher degrees in foreign countries. However, there is evidence as shown by the IMF (2002) that such issues are being addressed by governments in the subSaharan region. Legal protection of intellectual capital and investment in intangible assets should also be equally addressed by governments in the sub-Saharan Africa. It is not that intellectual capital and intangible assets do not get any legal protection at all in sub-Saharan Africa. It is that there is not much evidence to show the type of legal protection that is provided to intellectual capital and intangible assets in the region.

\subsection{Competent management}

Competent management is prerequisite to creating value from knowledge-based and intangible assets. The ability to create value from intellectual assets is contingent on the management capabilities of individual firms and the implementation of appropriate business strategies. Leading firms have increased the efficiency of their research and development processes by linking internal research and development activities more closely to their business strategy and relying on external sources to gain access to complementary knowledge and round out technology portfolios (OECD 2007). The likelihood of success also appears to increase when management ensures that, before research and development projects are initiated, there is clear customer demand for the new products or services and a profitable way to bring them to market (Jaruzelski \& Dehoff 2007). In the area of intellectual property, a number of firms have achieved considerable revenue growth through the adoption and active implementation of intellectual asset management procedures. These aim to realize value from patented inventions through licensing and sale, to transfer low-value patents to venture capital enterprises and to link patents better with innovation through incorporation into improved products 
and services (Moreno, Paci \& Usai 2006). Such techniques are particularly important in competitive industries where innovative products rapidly become commodities through follow-on innovation and imitation (OECD 2008). At the microeconomic level, work on the impact of research and development, patents, human capital and software shows not only that the average returns to investments in intellectual assets can be large, but also that the value of many intellectual assets is highly skewed. For example, a small number of patents can account for the bulk of the value of firms' patent portfolios (Harhoff et al., 1999).

The issue of competent management of intangible assets in sub-Saharan Africa is a little tricky. This is because in many sub-Saharan African countries, intangible assets are not very well understood and deciding on who can be a competent manager is not easy. The trend may be changing but in most sub-Saharan Africa countries, managers of most government enterprises are not appointed according to merit as opposed to one's connections in government.

Many research and development projects do not result in a successful new product or service, but the returns from successful projects can more than compensate. The role of management is to direct investment to areas of higher expected returns and develop processes that ensure that those returns are realized. There is now significant empirical work to support the view that effective use of intellectual assets and technologies depends on the quality of management. However, management practices, including management of human capital and technology, setting targets and reporting on performance, have been shown to vary widely both within and between countries and within industries (Bloom \& van Reenen 2010).

\subsection{Policy challenges in creating and retaining value of intangible assets in sub-Saharan Africa}

In sub-Saharan Africa, creating innovations and value through the efficient use of intangible assets may be looked upon as being primarily the role of the private sector. However, public policy is important in facilitating an enabling environment for creating innovations and value through the efficient use of intangible assets. There is no doubt that better information on intellectual assets in the national accounts and corporate balance sheets would facilitate the implementation of more efficient public policies. Likewise both public policy and corporate strategy making would benefit from a better recognition of the impact of investing in intellectual assets to generate economic value by way of creating employment and generating taxes. As intellectual assets contribute a larger share of economic value, policy makers will be confronted with a growing need to balance the benefits of gaining control over them against the benefits of mobility and open access. Any discussion of policies in an area such as the monetization of intangibles must at least acknowledge the broader issues of innovation and economic competitiveness (Jarboe, Furrow \& Athena Alliance, 2008). Jarboe and Furrow and Athena argue that areas such as macroeconomics, education, worker training, research and development funding, and entrepreneurship lay the groundwork for the creation and utilization of intangible assets. Innovation is, in part, predicated on these policies. However, other areas of policy, such as technology transfer, intellectual property rights, taxation, etc., directly impact the monetization process.

It is the contention of Jarboe, Furrow and Athena Alliance (2008) that the economic rules have changed, but public policy has not caught up. They argue that governments are struggling with ways to utilize information, foster development of intangibles, and promote innovation and competitiveness in this new economy. The new economy is interpreted to mean a knowledge-based economy. Policymakers are grappling with the urgent need to frame policy questions in light of the changing economic situation but they are yet to formulate sound policies on how to utilize information, knowledge and other intangibles. Issues of developing and utilizing information, managing intangibles, and fostering innovation underlie discussions on a variety of subjects, such as intellectual property rights, education and training policy, economic development, technology policy, and trade policy. Crafting new policies in these areas requires infusing a better understanding of intangibles and the information economy into the public debate.

As the nature of innovation becomes more collaborative, public policy makers in sub-Saharan Africa should formulate policies which allow and enable co-innovation across firms, and beyond national boundaries. Public policies in subSaharan Africa need to strike a proper balance between private and public goals. There is need for further exploring the trade-offs between open and controlled access to intellectual assets and their effects on business innovation and economic performance, especially in an environment that is quickly changing because of developments in information and communication technologies, especially with the Internet and high speed broadband communications networks. Access to the Internet in sub-Saharan Africa is low compared to other regions, but it can be improved. Public policy formulators in sub-Saharan Africa should be aware of the fact that easy availability of non-financial information about firms' intangible assets is consistent, comparable over time and across corporations, would allow investors to more easily assess future earnings and the risks associated with different investment opportunities. It may also contribute to making financial markets more efficient. Improved availability of information about intangible assets and company strategy also improves the ability of firms to secure funding at a lower cost of capital. Public policies in sub-Saharan Africa should take into 
account the diverse nature of intellectual assets, which also tend to vary by firm and by industry. There is no evidence that to date, best practices have been widely disseminated and governments in sub-Saharan Africa could play a role in helping to diffuse those pioneered by high-performance firms based in other regions of the world. Highlighting the potential benefits of disclosure may also encourage more companies to improve their disclosure practices as well as their internal management systems.

Innovation goes hand in hand with research and development, as well as science and technology. Any policies on innovation strategy should cover research and development and science and technology. In most sub-Saharan Africa countries, strategy still consists largely of statements of good intent and overambitious plans. Overall, science and technology policy exists largely on paper, and comes very low in the pecking order of government priorities. This differs greatly from the dynamic Asian developing countries (Amsden 2000; Lall 1996), where technology upgrading and strategy have become important policy priorities. The most fundamental policy gap in sub-Saharan Africa is perhaps the lack of official appreciation of the importance of technology development to manufacturing growth and competitiveness without such appreciation clearly no effective strategies can be formulated or implemented. Governments in the region pay little attention to technological needs in industry or to the promotion of technological activity within firms or in support institutions. Not only does industry lack a technology culture, so do the governments in the region. Lall and Piettrobelli (2005) are of the opinion that no national technology system can function effectively unless such a culture is created.

\section{Conclusion}

There is no doubt that intangible assets are increasingly gaining importance in the modern knowledge economy. It is important to identify knowledge-based assets as they are invisible and intangible. Because of their nature, knowledgebased assets are not captured very well by any of the traditional measures, accounting or otherwise, that corporations and government departments master in their everyday operations. Sub-Saharan Africa may not be considered as part of the global knowledge economy, but effective development and deployment of intellectual assets in the region may fuel value creation both in terms of expansion of the stock of wealth and in the generation of current value through new or improved products and processes. One major challenge is that intangible assets are yet to be well measured and the value creation mechanism is not yet well understood, more so in sub-Saharan Africa. Failure to correctly assess the value of intangible assets as it happens in sub-Saharan Africa can lead to misallocation of resources and other inappropriate decisions by corporate and institutional managers, public policy makers and others. Policy makers in sub-Saharan Africa need to be educated on the importance of formulating public policies which promote the exploitation and use of knowledge-based assets.

Sub-Saharan Africa requires new business models. Intangible assets have proved to be important for innovation, and in particular non-technological innovation and other new forms of innovation. There is urgent need to examine the impact of intangible assets on the emergence of new business models in sub-Saharan Africa. Equally, intangible assets have the potential to play an important role in the increasing fragmentation of global value chains and in the globalization of business services. Corporations and researchers in sub-Saharan Africa should explore the relationship between intellectual assets, organisational learning and organizational change, with particular regard to value creation in the fast globalizing world economy.

Efforts to compile data series on intellectual assets and to assess returns to the related investments face the measurement challenges like definition of asset boundaries and determination of appropriate depreciation rates and deflators. For purposes of achieving comparability, conventions may need to be developed. Elsewhere, efforts are underway to better assess the measurement and policy dimensions of intangible assets at the national level. Governments and business leaders in sub-Saharan Africa recognize the potential economic importance of intangible assets. Consideration of intangible assets is a part of the path to a more complete understanding of economic developments and enhanced policy responses for the future, including with respect to such issues as growth, resource allocation, adjustment and competitiveness (OECD 2007).

The discussion in this article suggests that in a knowledge economy, intangible assets are of immense importance in generating wealth and contributing to GDPs of countries around the world. Valuing knowledge-based and intangible assets is clearly not a straightforward exercise. Each valuation method prescribed by accountants is subject to strengths, weaknesses and complexities and yet none are able to provide a universally indisputable, accurate and reliable value. Although these values are not as robust as we would hope, it is certainly better to attempt to attribute value to intangible assets than classifying everything as either goodwill or organizational culture. 


\section{References}

Abdullah, W.M. 2004. Critical concerns in transfer pricing and practice. Westport, CT: Praeger Publishers.

Adams, J., King, C. \& Hook, D. 2010. Global research report: Africa. [Online]. http://www.umbb.dz/site-bib/pdf/ globalresearchreport-africa.pdf. (Accessed 28 May 20I I).

Advisory Committee on Measuring Innovation in the $21^{\text {st }}$ Century Economy. 2008. Innovation measurement tracking the state of innovation in the American economy: a report to the Secretary of Commerce. [Online]. http://www.innovationmetrics.gov/ Innovation\%20Measurement\%200 I-08.pdf. (Accessed 30 May 20I I).

Amsden, A.H. 2000. The rise of the rest: late industrialization outside the North Atlantic Region, New York: Oxford University Press.

Andreou, A.N., Green, A. \& Stankosky, M. 2007. A framework of intangible valuation areas and antecedents. Journal of Intellectual Capital, 8: 52-75.

Andriessen D. 2004. Making sense of intellectual capital - designing a method for the evaluation of intangibles. Boston: Elsevier Butterworth-Heinemann.

Baregheh, A., Rowley, J. \& Sambrook, S. 2009. Towards a multidisciplinary definition of innovation. Management Decision, 47(8): I323-1339.

Barney, J. 1986. Organizational culture: can it be a source of sustained competitive advantage? Academy of Management Review, II (3):656-665.

Barney, J. 199I. Finn resources and sustained competitive advantage. Journal of Management, I7: 99- 120.

Basu, A., Calamitsis, E.A. \& Ghura, D. 2000. Promoting growth in sub-Saharan Africa: learning what works. [Online] http:// www.imf.org/external/pubs/ft/issues/issues23/index.htm. (Accessed 31 July 20I0).

Blair, M.M. \& Wallman, S.M. 200I. Unseen wealth: report of the Brookings Task Force on Intangibles. Washington, D.C.: Brookings Institution Press.

Bloom, N. \& Van Reenen, J.M. 2010. Why do management practices differ across firms and countries? Journal of Economic Perspectives, 24(I):203-224.

Carmeli, A. \& Tishler, A. 2004. The relationships between intangible organizational elements and organizational performance. Strategic Management Journal, 2503: I257-I278.

Corrado, C., Hulten, C. \& Siche, D. 2005. Measuring capital and technology: an expanded framework”, in Corrado, C. Haltiwanger, J. and Sichel, D. (eds). Measuring capital in the new economy. Chicago: University of Chicago Press, I I-46.

Corrado, C., Hulten, C. \& Sichel, D. 2006. Intangible capital and economic growth, NBER Working Paper No. I I948. [Online]. http://www.aueb.gr/deos/seminars/Corrado_24-10-07.pdf. (Accessed 27 July 2010).

Davenport, T. \& Prusak, L. 1998. Working knowledge: how organizations manage what they know. Boston: Harvard Business School Press.

Department for Innovation, Universities and Skills, United Kingdom. 2008. Innovation nation: a report presented to Parliament by the Secretary of State for Innovation, Universities \& Skills, the Chancellor of the Exchequer and the Secretary of State for Business Enterprise and Regulatory Reform by Command of Her Majesty. [Online] http://webarchive.nationalarchives.gov.uk/tna/+/http:// www.dius.gov.uk/publications/scienceinnovation.pdfl. (Accessed I6 July 2010).

Diefenbach, T. 2006. Intangible resources: a categorical system of knowledge and other intangible assets. Journal of Intellectual Capital, 7(3):406-420.

Dierickx, I. \& Cool, K. 1989. Asset stock accumulation and sustainability of competitive advantage. Management Science, 35:I504-I5II.

Dosi, G. 1990. Finance, innovation and industrial change. Journal of Economic Behavior \& Organization, I3(3):299-319.

Drucker, P. 1993. Post-capitalist society. Oxford: Butterworth Heinemann.

Edvinsson, L. \& Malone, M. 1997. Intellectual capital: realizing your company's true value by finding its hidden brainpower. New York, NY: Harper Collins.

Ellis, I. 2009. Maximizing intellectual property and intangible assets. [Online]. http://www.athenaalliance.org/pdf/ MaximizingIntellectualPropertyandIntangibleAssets.pdf. (Accessed I0 May 2010).

Farok. J. (ed.) 200 I. Valuation of intangible assets in global operations. Westport, CT: Quorum Books.

Flignor, P. \& Orozco, D. (n.d.). Intangible assets and intellectual property valuation: a multidisciplinary perspective. [Online]. http://www.wipo.int/sme/en/documents/ip_valuation.htm\#legal. (Accessed 22 April 2010).

Fombrun, C. 1996. Reputation: Realizing value from the corporate linage. Boston: Harvard Business School Press.

Forbes, T. 2008. Why it is hard to value a mystery. Financial Times, Monday 7, October 2008. [Online]. http:// www.intangiblebusiness.com/Brand-Services/Financial-services/Press-coverage/Why-it-is-hard-to-value-a-mystery $\sim 969$. html. (Accessed May $2 \mathrm{I} 20 \mathrm{II}$ ).

Furubotn, E.G. \& Pejovich, S. 1974. Introduction: the new property rights literature. In Furubotten, E.G. \& Pejovich, S. (eds). The economics of property rights. Cambridge, MA: Ballinger Publishing Company, pp. I-9.

Grant, R.M. 1997. The knowledge-based view of the firm: implications for management practice. Long Range Planning, 30(3): 450-454.

Gurteen, D. 2006. The Gurteen perspective. [Online]. http://www.ikmagazine.com/display.asp?articleid=AE03FICA-F94B-4BD59BE9-0CB68079CB6F. (Accessed 30 April 2010).

Hall, R. 1992. The strategic analysis of intangible resources. The Strategic Management Journal, I3: I 35- I44.

Hall, R. 1993. A framework for linking intangible resources and capabilities to sustainable competitive advantage. The Strategic Management Journal, 14:607-618.

Harhoff, D., Narin, F., Scherer, F.M. \& Vopel. K. 1999. Citation frequency and the value of patented inventions. Review of Economics and Statistics, 8I: 5I I-5I5.

Hauser, J.R. \& Katz, G.M. 1998. Metrics: you are what you measure. European Management Journal, 16: 5 I 7-528.

SA Jnl Libs \& Info Sci 20II, 77(2) 
International Monetary Fund (IMF). 2002. Education for all. Finance and Development: A Quarterly Magazine of the IMF, 39(I). [Online]. http://www.imf.org/external/pubs/ft/fandd/2002/03/mingat.htm. (Accessed I0 May 20I0.)

Itami, H. 1984. Invisible resources and their accumulation for corporate growth. Hitotsubahi Journal of Commerce \& Management, 19: 20-39.

Jarboe, K., Furrow, R. \& Athena Alliance 2008. Intangible assets monetization: the promise and the reality. [Online]. http:// www.athenaalliance.org/pdf/IntangibleAssetMonetization-ExeSumm.pdf. (Accessed 28 June 20I0).

Jaruzazelski, B. \& Dehoff, K. 2007. The customer connection: the global innovation 1000. [Online]. http://www.glevinton.com/ uploads/Customer_Connec.pdf. (Accessed May 23, 20I I)

Kaplan, R.S. \& Norton, D.P. 2004a. Strategy maps: converting intangible assets into tangible outcomes. Boston: Harvard Business School Press.

Kaplan, R.S. \& Norton, D.P. 2004b. Measuring the strategic readiness of intangible assets. Harvard Business Review, February 2004. [Online]. http://ibmstudies.com.np/files/Hardvard\%20Articles/Harvard\%20Business\%20Review\%20\%20February\%202004\%20(Complete\%20lssue).pdf. (Accessed May 25 201 I).

Lall, S. 1996. Learning from the Asian tigers: studies in technology and industrial policy. London: Macmillan.

Lall, S. \& Pietrobelli, C. 2005. National technology systems in sub-Saharan Africa. International Journal of Technology and Globalization, I(3/4): 3 II-342.

Lazaric, N. \& Marengo, L. 2000. Towards a characterization of assets and knowledge created in technological agreements: some evidence from the automobile robotics sector. Industrial and Corporate Change, 9: 53-86.

Levey, M.M. 200I. Transfer pricing - what is next. International Tax Review, June: 91-92.

Moreno, R., Paci R. \& Usai S. 2006. Innovation clusters in the European regions. European Planning Studies, I4(9):?.

Morrow, N.M. 200I. Knowledge management: an introduction. In Williams, M.E. (ed.) Annual Review of Information Science and Technology (ARIST): 35:381-422.

Myers, S.P. 1996. Knowledge management and organizational design. Boston: Butterworth-Heinemann.

Nelson, R. \& Winter, S. 1982. An evolutionary theory of economic change. Cambridge: Harvard University Press.

Nonaka, I. \& Takeuchi, H. 1995. The knowledge-creating company: how Japanese companies create the dynamics of innovation. Oxford: Oxford University Press.

OECD. 2007, Compendium of OECD work on intellectual property (IP). OECD: Paris.

OECD. 2008. Creating value from intellectual assets. [Online]. http://www.oecd.org/dataoecd/53//9/3670/575.pdf. (Accessed I5 June 2010).

Penrose, E.T. 1959. The theory of the growth of the firm. New York: Wiley.

Polanyi, M. 1958. Personal knowledge: towards a post-critical philosophy. New York, NY: Routledge.

Porter, M. 1996. What is strategy? Harvard Business Review, November-December: 6I-78.

Prahalad, C.K. \& Hamel, G. 1990. The core competence of the corporation. Harvard Business Review, 68 (5-6):79-93.

Rao, H. 1994. The social construction of reputation: certification contests, legitimation, and the survival of organizations in the American automobile industry. Strategic Management Journal, 15:29-44.

Roberts, P.W. \& Dowling, G.R. (2002). Corporate reputation and sustained superior financial performance. Strategic Management Journal, 23:1077-1093.

Rumelt, R.P. 2003. What in the world is competitive advantage? Policy working paper, 2003-I5. [Online]. http:// www.anderson.ucla.edu/faculty/dick.rumelt/Docs/Papers/WhatisCA_03.pdf. (Accessed I 3 July 2010).

Saloner, G., Shepard, A. \& Podolny, J. 200I. Strategic management. New York: John Wiley and Sons.

Skyrme, D.J. 1999. Knowledge networking: creating the collaborative enterprise. Oxford: Butterworth-Heinemann.

Stewart, T.A. 1997. Intellectual capital: the wealth of new organizations. London: Nicholas Brealey Publishing.

Teece, D.J. 2000. Managing intellectual capital. New York, NY: Oxford University Press.

Tissen, R., Andriessen, D. \& Deprezz F. L. 1998. Value-based knowledge management. Amsterdam: Addison Wesley Longman.

UNESCO. 2007. Science in Africa. [Online]. http://www.unesco.org/science. (Accessed 3I July 20 I0).

Usai, S. 2008. Report on the geography of innovation activity in OECD regions. OECD DSTI Working Paper 2008/3. [Online]. http://www.oecd.org/dataoecd/4I/52/4I 77I 23I.pdf. (Accessed 22 June 2010.

Wemerfelt, B. 1984. A resource-based view of the firm. Strategic Management Journal, 5(2): I 7 I- I 80.

World Bank. 20I0. The changing wealth of nations. Washington, D.C.: The World Bank.

World Bank. 20II). Regional fact sheet from the World Bank Development Indicators, April 20I I: Sub-Saharan region data from WDI databases. [Online]. http://search.worldbank.org/data?qterm=sub-saharan + africa +-+ inernet $+a c c e s s+20 \mathrm{I} / \&$ language $=$ \&format. (Accessed 30 May 20II).

World Bank. 20II. Global innovation policy dialogue on innovation in Sub-Saharan Africa: description. [Online]. http:// web.worldbank.org/WBSITE/EXTERNAL/WBI/WBIPROGRAMS/KFDLP/0,,contentMDK:20292227 pagePK:64I56I58

piPK:64 I52884 theSitePK:46I I98,00.html. (Accessed 30 May 20I I). 